\title{
THE CRUSTAL STRUCTURE OF ONEGA-KANDALAKSHA PALEORIFT IDENTIFIED BY COMPLEX ANALYSIS OF THE ANOMALOUS MAGNETIC FIELD OF THE WHITE SEA
}

\author{
A. S. Baluev1, Yu. V. Brusilovsky², A. N. Ivanenko² \\ 1 Geological Institute of RAS, Moscow, Russia \\ 2 P.P. Shirshov Institute of Oceanology RAS, Moscow, Russia
}

\begin{abstract}
Geological and geophysical studies recently conducted in the White Sea and the adjacent territory have provided new data on the deep structure of this region. Our study aims to conduct complex analysis of the anomalous magnetic field and the geological and geophysical data on the Onega-Kandalaksha paleorift located in the White Sea basin and the adjacent southeastern land area, and to develop a model showing its deep structure. The basis for analysing the magnetic field is the anomalous magnetic field (AMF) map constructed by the authors using the magnetic survey data consolidated by the Marine Arctic Geological Expedition (MAGE) in 2003-2008 and supplemented by the survey data of the Institute of Oceanology RAS in 2001-2004. The parameters of the magnetically active layer are estimated by the independent complementary methods of quantitative interpretation developed by the Laboratory of Geophysical Fields, P.P. Shirshov Institute of Oceanology RAS. This article describes a model showing the structure and formation of the magnetically active layer of the White Sea paleorift. Our study shows that the magnetically active layer of the paleorift system has a complex structure reflecting all the main stages in the evolution of tectonic activity in the White Sea region, from the Middle and Late Riphean to the last glaciation of the Quaternary period. The model includes three structural layers, each corresponding to a certain stage. The bottom structural layer is the base of the magnetically active layer, which reflects the continental rifting stage in the evolution of the White Sea mobile belt in the Middle and Late Riphean. The middle structural layer reflects the Middle Paleozoic (Late Devonian) stage of rifting reactivation, which is characterized by alkaline-ultrabasic magmatism and represented by swarms of alkaline dykes and diatremes, including kimberlite pipes. The top structural layer reflecting a high-frequency component of the AMF is related to the highly magnetic sources of anomalies located in the upper part of this structural layer. The characteristics of the top structural layer suggest that it formed in the Late Pleistocene - Holocene and developed during the final stage the tectonic activation of this region. The deep crustal structure of the White Sea basin is specified in our model showing the magnetically active layer for the low-frequency component of the AMF. In the southeastern part of the basin, magmatism products of the basic (Riphean - Vendian) and alkaline-ultrabasic (Middle Paleozoic) composition are abundant in the crust and provide for a strong magnetic source of anomalies, the lower edges of which are traced at the depths to $30 \mathrm{~km}$. This probably reflects the most active plume-lithospheric interaction. Wedging and uplifting of the magnetically active layer northwestward along the Onega-Kandalaksha rift is related to the White Sea
\end{abstract}

RESEARCH ARTICLE

Received: February 9, 2018

Revised: September 13, 2018

Accepted: September 21, 2018

For citation: Baluev A.S., Brusilovsky Yu.V., Ivanenko A.N., 2018. The crustal structure of Onega-Kandalaksha paleorift identified by complex analysis of the anomalous magnetic field of the White Sea. Geodynamics \& Tectonophysics 9 (4), 1293-1312. doi:10.5800/GT-2018-9-4-0396.

Для цитирования: Балуев А.С., Брусиловский Ю.В., Иваненко А.Н. Структура земной коры Онежско-Кандалакшского палеорифта по данным комплексного анализа аномального магнитного поля акватории Белого моря // Геодинамика и тектонофизика. 2018. Т. 9. № 4. C. 1293-1312. doi:10.5800/GT-2018-9-4-0396. 
(Belomorsky) deep fault. This fault is a long-lived conduit that channels magma from the central portion of the plume, as evidenced by the igneous bodies of the basic composition in the basement and central parts of the sedimentary wedge in the Kandalaksha graben. The complex analysis of the AMF in the White Sea region suggests the presence of morphologically different igneous bodies in the upper crust in the study region.

Key words: White Sea paleorift system; riftogenesis; magnetic layer model; inverse problem; field separation; effective magnetization

\title{
СТРУКТУРА ЗЕМНОЙ КОРЫ ОНЕЖСКО-КАНДАЛАКШСКОГО ПАЛЕОРИФТА ПО ДАННЫМ КОМПЛЕКСНОГО АНАЛИЗА АНОМАЛЬНОГО МАГНИТНОГО ПОЛЯ АКВАТОРИИ БЕЛОГО МОРЯ
}

\author{
А. С. Балуевㅜ, Ю. В. Брусиловский${ }^{2}$, А. Н. Иваненко² \\ ${ }^{1}$ Геологический институт РАН, Москва, Россия \\ ${ }^{2}$ Институт океанологии им. П.П. Ширшова РАН, Москва, Россия
}

\begin{abstract}
Аннотация: Благодаря геолого-геофизическим исследованиям последних лет акватории Белого моря и прилегающей территории появились новые данные о глубинном строении Беломорского региона. Основная цель представляемой работы - составление на основе комплексного анализа аномального магнитного поля и других геолого-геофизических данных модели глубинного строения Онежско-Кандалакшского палеорифта, расположенного в Беломорском бассейне и на прилегающей с юго-востока суше. Основой для анализа магнитного поля Белого моря послужила сводная карта аномального магнитного поля (АМП), составленная авторами по материалам магнитных съемок, выполненных ОАО «Морская арктическая геологоразведочная экспедиция» (МАГЭ) в 2003-2008 гг., которые были дополнены материалами съемок, выполненных Институтом океанологии РАН в 2001-2004 гг. Для решения этой задачи и оценки параметров магнитоактивного слоя в работе были использованы независимые взаимодополняющие методы количественной интерпретации, разработанные в лаборатории геофизических полей Института океанологии им. П.П. Ширшова РАН. В результате анализа и комплексной интерпретации аномального магнитного поля и других геолого-геофизических данных авторами была создана модель строения и формирования магнитоактивного слоя палеорифтовой системы Белого моря. Исследования показали, что магнитоактивный слой палеорифтовой системы Белого моря имеет сложное строение, которое отражает все основные этапы тектонической активности Беломорского региона - от среднего и позднего рифея до событий последнего оледенения четвертичного периода. Модель магнитоактивного слоя представлена тремя структурными уровнями (горизонтами), каждый из которых отражает определенный этап формирования изучаемой площади. Нижний структурный уровень (основание магнитоактивного слоя) отражает рифтовый этап эволюции Беломорского подвижного пояса в среднем и позднем рифее, характеризующийся проявлением континентального рифтогенеза. Средний структурный горизонт отражает среднепалеозойский (позднедевонский) этап реактивации рифтовой системы, который характеризуется проявлением щелочно-ультраосновного магматизма и представлен роями щелочных даек и трубок взрыва, в том числе и кимберлитового состава. Верхний структурный уровень отражает высокочастотную составляющую аномального магнитного поля и связан с сильномагнитными источниками аномалий, расположенными в верхней части выделяемого структурного уровня. Характеристики этого структурного уровня позволяют предполагать, что верхний горизонт мог быть сформирован во время последнего этапа (поздний плейстоцен - голоцен) тектонической активизации этого региона. Модель магнитоактивного слоя для низкочастотной составляющей АМП отражает глубинное строение земной коры Беломорского бассейна, в юго-восточной части которого сильномагнитным источником аномалий с глубиной нижних кромок до 30 км является насыщенность коры продуктами проявлений магматизма основного (рифей - венд) и щелочноультраосновного (средний палеозой) состава, что, вероятно, отражает наиболее активное плюм-литосферное взаимодействие. Выклинивание и воздымание магнитоактивного слоя к северо-западу вдоль простирания Онежско-Кандалакшского рифта связывается с Беломорским глубинным разломом, который являлся долгоживущим магмоподводящим каналом от центральной части плюма, что подтверждается наличием магматических тел основного состава в фундаменте и в центральной части осадочного клина, выполняющего Кандалакшский рифтогенный грабен. Комплексный анализ АМП в пределах акватории Белого моря позволил также спрогнозировать наличие магматических тел различной морфологии в верхней части земной коры.
\end{abstract}

Ключевые слова: палеорифтовая система Белого моря; рифтогенез; модель магнитоактивного слоя; обратная задача; разделение полей; эффективная намагниченность 


\section{1. ВВЕДЕНИЕ}

Изучение глубинного строения земной коры всегда являлось одной из важнейших задач в геологии, и, в частности, особый интерес вызывают те ее участки, которые претерпели деструкцию в ходе своей эволюции. В данном случае это касается северо-восточного сегмента Восточно-Европейского кратона, фундамент которого разбит структурами континентального рифтинга рифейского заложения. Эти структуры объединяются в палеорифтовую систему Белого моря, которая выделяется в рельефе кристаллического фундамента платформы системой рифтогенных желобов, располагающихся субпараллельно вдоль северо-восточного края платформы и погружающихся к юговостоку под чехол Мезенской синеклизы. Северозападная часть палеорифтовой системы местами раскалывает выходящий на поверхность кристаллический фундамент платформы (Балтийский щит) и скрыта под водами Белого моря. Палеорифтовая система Белого моря заложилась в среднем рифее на раннедокембрийском консолидированном основании, пережила этап активизации в среднем палеозое, когда широкое развитие получил щелочной магматизм, и в конце кайнозоя, когда образовался современный бассейн Белого моря. Общая протяженность палеорифтовой системы Белого моря достигает более 1000 км при ширине от 300 до 500 км. В эту систему рифтовых зон входят Онежско-Кандалакшский, Керецко-Пинежский, Чапомско-Лешуконский и Мезенский палеорифты, разделенные выступами кристаллического фундамента. С юговостока палеорифтовая система Белого моря ограничена Котласским грабеном. С северо-востока систему палеорифтов Белого моря перекрывает краевой шов Тимано-Варангерской системы байкалид (кадомид) (рис. 1).

В последние годы были выполнены значительные объемы комплексных геофизических исследований (сейсмическое профилирование, сопровождаемое гравимагнитной съемкой) акваторий Белого и южной части Баренцева моря (ОАО МАГЭ) и в наземной части европейского севера России в пределах Мезенской синеклизы (ПГО «Спецгеофизика»), а также полевые исследования на территории северо-восточной части Балтийского щита и юго-восточного Беломорья. Благодаря этим исследованиям появилась возможность более детального изучения глубинного строения территории Беломорья, однако решение этой задачи пока имеет неоднозначную трактовку в силу ряда как объективных, так и субъективных причин, отражающих различные взгляды исследователей.

\section{2. ИСТОРИЯ ИССЛЕДОВАНИЙ И ГЕОЛОГО-ГЕОФИЗИЧЕСКАЯ ИЗУЧЕННОСТЬ ТЕРРИТОРИИ БЕЛОМОРЬЯ}

Изучение глубинного строения земной коры территории Беломорья началось достаточно давно - примерно в середине прошлого века. Идея о существовании в пределах юго-восточного обрамления Балтийского щита прогибов фундамента была впервые выдвинута Л.Я.Харитоновым в 1955 г. [Kharitonov, 1955]. Согласно его выводам, Кандалакшско-Онежская синклинальная структура выделялась на основе анализа и сопоставления мощностей терригенных рифейских отложений Кандалакшского залива и Онежского полуострова Белого моря с особенностями структуры Балтийского щита. При этом отмечалось ярко выраженное северозападное простирание и пологое падение крыльев прогиба, не превышающее $10^{\circ}$. По данным стратиграфического анализа возраст образования структуры оценивался в интервале от верхнего протерозоя до верхнего девона. Опираясь на интерпретацию материалов аэромагнитной съемки, Р.А. Гафаров [Gafarov, 1963] охарактеризовал прогиб как Онего-Кандалакшскую синклиналь. В работах B.H. Зандера [Zander, 1972; Zander et al., 1967] эта структура представлялась как Кандалакшский грабен (авлакоген). Уточнение контуров производилось им по данным геофизических исследований, прежде всего аэромагнитных съемок. При этом глубина залегания фундамента была оценена в 3 км. Отмечалась также унаследованность простирания и приуроченность основных структурных элементов к зонам глубинных разломов дорифейского заложения.

В результате анализа данных бурения, аэромагнитной и гравиметрической съемки А.А. Константиновским [Konstantinovsky, 1977] были уточнены параметры структуры, подчеркнуто сегментированное строение Онежско-Кандалакшского грабена и выделены три впадины: Онежская, Центральная и Кандалакшская. Уточнение данных о морфологии разрывных нарушений, стратиграфии и магматизме региона позволило ему сделать вывод о рифтовой природе грабена и о возможности сопоставления глубинного магматизма палеорифта с таковым современных рифтовых зон, хотя при этом отмечался большой временной разрыв между эпохой формирования грабена и внедрением магм.

Р.Н.Валеев [Valeev, 1978] рассматривал эту структуру уже как Кандалакшско-Двинский авлакоген, расчлененный на ряд сегментов (СевероКандалакшский, Кандалакшский, Яренгский, Северо-Двинский и Нижнетойменский) системой поперечных сдвигов, устанавливаемых по плановым смещениям магнитных аномалий, отвечающим вторичным деформациям магнитных тел. Образо- 


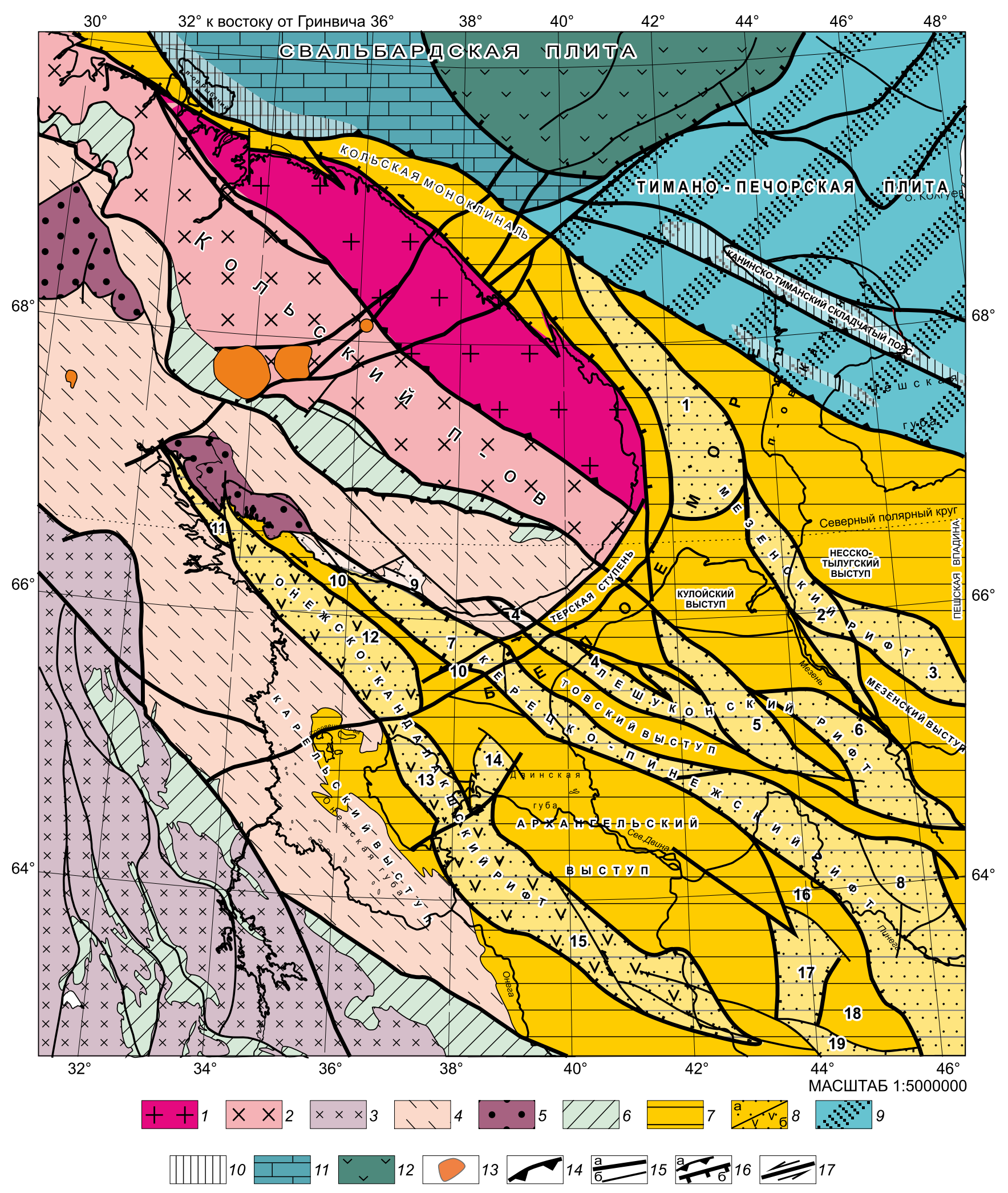

Рис. 1. Схема тектонического районирования северо-восточного сегмента Восточно-Европейкой платформы и ее обрамления [Baluev et al., 2012].

Восточно-Европейский кратон, Балтийский щит (1-6): 1-2 - Кольский массив неоархейской консолидации: 1 Мурманский блок, 2 - Центрально-Кольский блок; 3 - Карельский массив неоархейской консолидации; 4-5 - Лапландско-Беломорский подвижный пояс палеопротерозойской консолидации: 4 - Беломорский пояс, 5 - Лапландско-Колвицкий гранулитовый пояс; 6 - проторифтогенные палеопротерозойские пояса; 7 - плитная часть кратона (Мезенская синеклиза); 8 - рифтогенные грабены, выполненные терригенными (а) и вулканогенно-осадочными (б) образованиями рифея. 
Западно-Арктическая платформа (9-12): 9-10 - Тимано-Печорская плита: 9 - с фундаментом байкальской консолидации, 10 - складчатые рифейско-вендские образования; 11-12 - Свальбардская плита: 11 - с фундаментом гренвильской консолидации, 12 - Южная впадина Восточно-Баренцевского рифтогенного трога; 13 - проявления среднепалеозойского магматизма (массивы ультраосновного-щелочного комплекса, 380-360 млн. лет); 14 - конвергентная граница литосферных плит; 15-17 - разломы: 15 -разломные зоны, ограничивающие крупные структуры земной коры (а), прочие разломы (б); 16 -взбросы, надвиги(а), сбросы (б); 17 - сдвиги. Цифры на карте - основные структурные элементы рельефа фундамента: грабены: 1 - Понойский, 2 - Усть-Мезенский, 3 - Сафоновский, 4 Чапомский, 5 - Лешуконский, 6 - Азопольский, 7 - Керецкий, 8 - Пинежский, 11 - Колвицкий, 12 - Кандалакшский, 13 - Центральный, 14 - Унский, 15 - Онежский, 17 - Покшеньгский, 19 - Северо-Двинский. Выступы: 9 - Варзугская моноклиналь, 10 - Оленицкий вал, 16 - Выйский выступ, 18 - Юльский выступ.

Fig. 1. Schematic map [Baluev et al., 2012] showing tectonic zoning of the northeastern segment of the East European platform and the adjacent areas.

East European Craton, Baltic shield (1-6): 1-2 - Kola massif of Neo-Archean consolidation: 1 - Murmansk block, 2 - Central Kola block; 3 - Karelian massif of Neo-Archean consolidation; 4-5 - Laplandia-White Sea mobile belt of Paleoproterozoic consolidation: 4 - White Sea belt, 5 - Laplandia-Kolva granulite belt; 6 - protoriftogenic Paleoproterozoic belts; 7 - plate segment of the craton (Mezensk syncline); 8 - rift grabens filled with terrigenous (a) and volcanogenic-sedimentary (б) Riphean deposits.

Western Arctic platform (9-12): 9-10 - Timan-Pechora plate: 9 - basement of Baikalian consolidation, 10 - Riphean-Vendian folded deposits; 11-12 - Svalbard plate: 11 - including the basement of the Grenvil consolidation, 12 - southern basin of the East Barents riftogenic ridge; 13 - indicators of Middle Paleozoic magmatism (ultrabasic-alkaline complex, 380$360 \mathrm{Ma}$ ); 14 - convergent boundary of the lithospheric plates; 15-17 - faults: 15 -fault zones between large crustal structures (a), other faults (б); 16 - reverse faults, thrusts (a), normal faults (б); 17 - strike-slip faults. The main structural elements of the basement are numbered: grabens: 1 - Ponoy, 2 - Ust-Mezensk, 3 - Safonov, 4 - Chapom, 5 - Leshukon, 6 Azopol, 7 - Kerets, 8 - Pinezh, 11 - Kolva, 12 - Kandalaksha, 13 - Central, 14 - Una, 15 - Onega, 17 - Pokshenga, 19 - North Dvina. Ledges: 9 - Varzuga monocline, 10 - Olenitsky Val, 16 - Vyisky ledge, 18 - Yulsky ledge.

вание Кандалакшского залива рассматривается им как фаза возрождения рифейского грабена в новейшее время. Наряду с Кандалакшско-Двинским Р.Н. Валеев описывает и Керецко-Лешуконский авлакоген, отделенный от первого Архангельским горстом. В его пределах им выделены Керецкий, Полтинский, Лешуконский и Усть-Вачергинский сегменты.

Такое понятие, как система Беломорского рифта, или Беломорская рифтовая система (наряду с Баренцевоморской), было введено в 1992 г. М.И. Добрыниной. В него она включила Кандалакшский грабен в акватории Белого моря, Онего-Двинский и Керецко-Лешуконский авлакогены на Русской плите. Комплексный анализ геофизических полей региона, различных сейсмических исследований и данных глубокого бурения использовался для выяснения роли рифтогенеза в образовании описываемой структуры. При сопоставлении рифейских рифтовых зон с современными отмечалось отсутствие под первыми выступа аномальной мантии, выраженного обычно на глубинных сейсмических разрезах и в физических полях современных рифтов, что объясняется сглаживанием мантийных неоднородностей с течением времени [Dobrynina, 1992].

В последние два десятилетия интерес к северу Восточно-Европейской платформы связан, прежде всего, с возможной нефтегазоносностью рифейских отложений, выполняющих рифтогенные прогибы. Традиционно эта территория рассматривалась как площадь развития континентального рифтогенеза в рифее, который предшествовал началу общего прогибания и формирования осадочного чехла Мезенской синеклизы. Новые данные, полученные при комплексных геолого-геофизических исследованиях акватории Белого моря, проведенных OАО МАГЭ в последние годы [Kazanin et al., 2006; Zhuravlev, 2007], а также результаты наземных исследований территории Беломорья последних лет [Aplonov, Fedorov, 2006; Baluev et al., 2009a, 2009b, 2012; u dp.] значительно изменили сложившиеся представления о строении земной коры этого региона.

Наиболее значимыми представляются морские комплексные геофизические исследования, выполненные ОАО МАГЭ в 2003-2008 гг. в Воронке, Горле и Бассейне Белого моря. Комплекс этих работ включал: МОВ ОГТ, гравиметрическую и магнитометрическую съемку, а также непрерывное сейсмоакустическое профилирование. Цель этих исследований заключалась в изучении верхней части земной коры и прогнозе нефтегазоносности в области развития грабенов Беломорско-Мезенской рифтовой системы [Zhuravlev et al., 2007]. На основе вы- 
шеприведенных геофизических исследований в ОАО МАГЭ на территорию акватории Белого моря и прилегающей суши были составлены и изданы в 2009 г. Государственные геологические карты РФ м-ба 1:1000000 третьего поколения, листы Q-35-38, a в Геологическом институте РАН совместно с ОАО МАГЭ была составлена «Тектоническая карта Белого моря и прилегающих территорий» в м-бе 1:1500000 [Baluev, 2012] и объяснительная записка к ней «Тектоника Белого моря и прилегающих территорий» [Baluev et al., 2012].

Кроме того, в 2001 г. в рамках проекта «Системы Белого моря» по программе РАН, в 49-м и 50-м рейcax НИС «Профессор Штокман» Институтом океанологии им. П.П. Ширшова РАН были выполнены геомагнитные градиентные съёмки в различных районах акватории Белого моря [Brusilovskii et al., 2003]. В 2003 г. Институтом океанологии им. П.П. Ширшова РАН по программе МЧС были выполнены магнитные съемки на двух полигонах в глубоководной части Кандалакшского грабена.

В данной работе представлены результаты изучения глубинного строения земной коры Беломорского региона, основанные на комплексном анализе аномального магнитного поля акватории Белого моря с использованием новых методов количественной интерпретации параметров магнитоактивного слоя, а также сопоставление полученных данных с результатами других методов исследований, проведенных в Беломорском бассейне.

\section{3. МЕТОДЫ АНАЛИЗА МАГНИТНОГО ПОЛЯ}

Основой для анализа магнитного поля Белого моря послужила сводная карта АМП, составленная авторами по материалам магнитных съемок, выполненных МАГЭ в 2003-2008 гг., которые были дополнены материалами съемок, выполненных Институтом океанологии РАН в 2001, 2003 и 2004 гг., и материалами, предоставленными авторам НПО «Архангельскгеология». На рис. 2 представлены площадь и профили морской магнитометрической съемки, отраженные в работе.

Аномальное магнитное поле отражает суммарное влияние источников аномалий, находящихся на разных глубинах. Крупные региональные аномалии связаны с глубинным строением земной коры, а характер, интенсивность и конфигурация локальных аномалий обусловлены источниками, расположенными в ее верхней части. Разделение поля на составляющие, обусловленные различными геологическими факторами, является важнейшей задачей при изучении внутреннего строения коры. Для решения этой задачи и оценки параметров магнитоактивного слоя в работе были использова- ны независимые, взаимодополняющие методы количественной интерпретации, разработанные в лаборатории геофизических полей Института океанологии РАН им. П.П. Ширшова [Ivanenko et al., 2012]. В трехмерном варианте это пакет программ Magdepth3D, который впервые был реализован при интерпретации магнитных съемок на Каспии [Ivanenko et al., 2012]. В рамках этого пакета оценка глубин до верхних и нижних кромок проводится двумя способами - стохастическим (по спектру поля) и детерминистским (алгоритм так называемой “эйлеровской деконволюции"). При анализе радиально осредненного спектра поля установлена приуроченность верхних кромок источников поля к нескольким структурным горизонтам (уровням). Выделение спектральной составляющей каждого предполагаемого горизонта позволило оценить глубину до его верхних и нижних кромок. Проверка получаемых геометрических параметров осуществлялась подбором простых моделей источников для изолированных аномалий. Количественная характеристика изменчивости геологической среды аномальная эффективная намагниченность - находилась решением линейной обратной задачи с контролем заданных свойств решения [Last, Kubik, 1983; Portniaguine, Zhdanov, 1999]. При этом широко привлекалась априорная информация - данные о рельефе дна, сейсмические данные, результаты интерпретации другой геолого-геофизической информации.

Для отдельных профилей была решена обратная задача методом подбора в формате 2.5D [Cooper, 1997]. При этом магнитоактивный слой не разделялся по вертикали, а представлялся набором вертикальных блоков с величиной эффективной намагниченности, отражающей интегральную намагниченность блока по глубине. Для уменьшения неоднозначности решения обратной задачи при оценке глубины верхних кромок привлекались данные о глубинах до фундамента.

При геологической интерпретации данных, полученных при обработке аномального магнитного поля, использовались данные морского сейсмического профилирования МОВ ОГТ, данные батиметрии и материалы по геологическому строению прилегающей суши.

\section{4. АНАЛИЗ МАТЕРИАЛОВ МАГНИТНЫХ ИССЛЕДОВАНИЙ ЦЕНТРАЛЬНОГО БАССЕЙНА БЕЛОГО МОРЯ}

Анализ карты АМП (рис. 3) показал, что на изучаемой площади отчетливо выделяются интенсивные положительные аномалии северо-западного простирания, которые прослеживаются из Двинского в Кандалакшский залив Белого моря. 


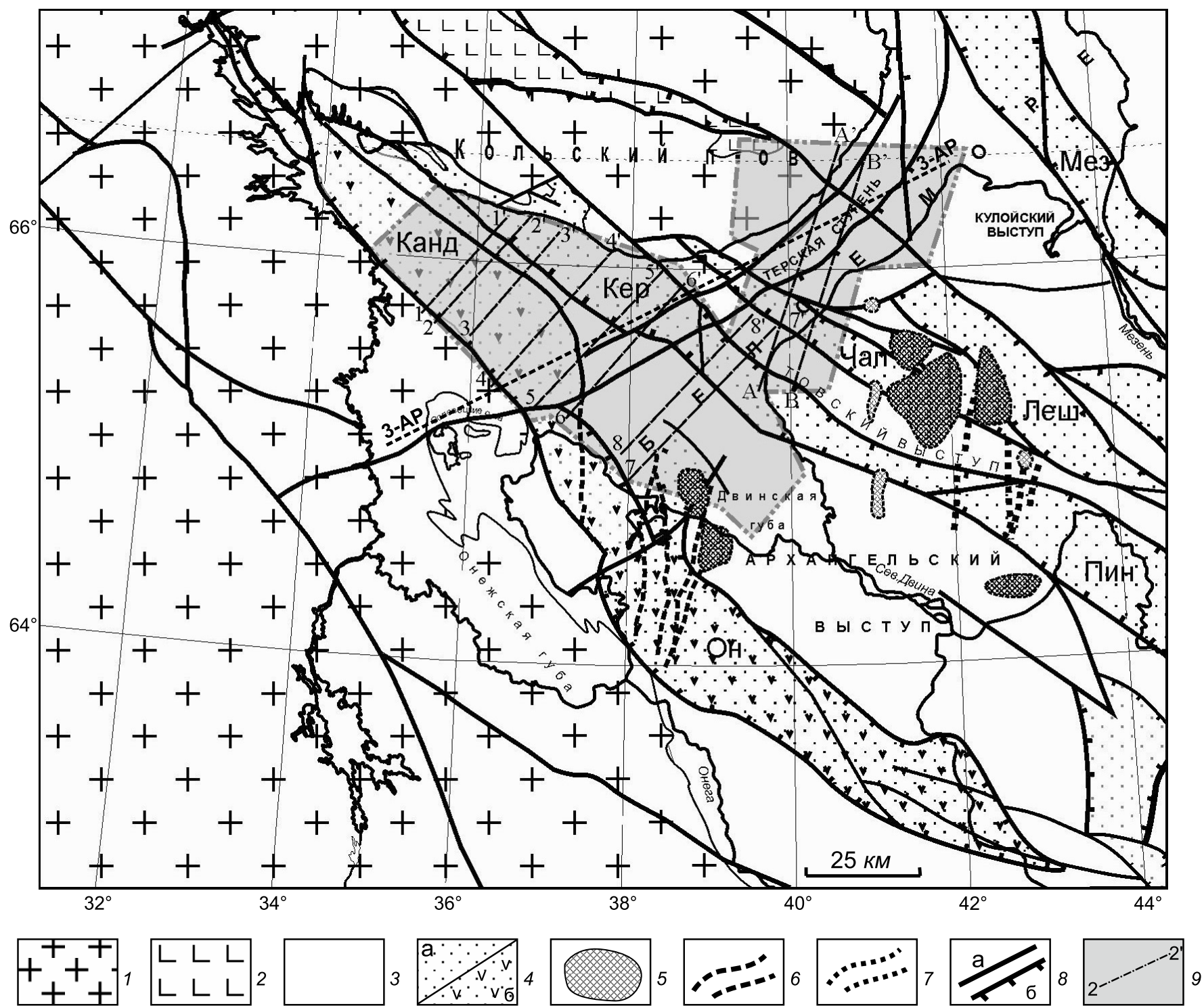

Рис. 2. Схема тектоники Беломорского региона (составлена с использованием работ [Baluev et al., 2012; Bush, Kalmykov, 2015].

1 - Балтийский щит; 2 - Имандра-Варзугский палеопротерозойский проторифтогенный пояс (вулканогенно-осадочная формация); 3 - плитная часть платформы, перекрытая осадочным чехлом; 4 - осадочное (а) и вулканогенно-осадочное (б) выполнение рифейских грабенов палеорифтовой системы Белого моря; 5 - ареалы проявления среднепалеозойского эксплозивного магматизма щелочно-ультраосновного состава; 6-7 - дайки базитов, не выходящие на поверхность: 6 - вендского возраста, 7 - среднепалеозойского возраста; 8 - разломы: а - неустановленной кинематики, б - сбросы и сдвиго-сбросы, ограничивающие рифтогенные грабены; 9 - площадь и профили морской магнитометрической съемки, отраженные в работе. Рифейские грабены: Канд - Кандалакшский, Он - Онежский, Кер - Керецкий, Пин - Пинежский, Чап - Чапомский, Леш - Лешуконский, Мез - Мезенский.

Fig. 2. Schematic tectonic map of the White Sea region (compiled using the data from [Baluev et al., 2012; Bush, Kalmykov, 2015]).

1 - Baltic shield; 2 - Imandra-Varzuga Paleoproterozoic protoriftogenic belt (volcanogenic-sedimentary formation); 3 - plate part of the platform overlaid by the sedimentary cover; 4 - sedimentary (a) and volcanogenic-sedimentary (б) infill of the Riphean grabens the White Sea paleorift system; 5 - areas showing the Middle Paleozoic explosive magmatism of the alkali-ultrabasic composition; 6-7 - basite dykes that do not reach the surface: 6 - Vendian, 7 - Middle Paleozoic; 8 - faults: a - unspecified kinematics, 6 - normal faults, and normal faults with shear component, which border the rift grabens; 9 - areas and profiles of the marine magnetometric surveys mentioned in the text. Riphean grabens: Канд - Kandalaksha, Он - Onega, Kep - Kerets, Пин - Pinega, Чап - Chapoma, Леш - Leshukonsky, Meз - Mezensk.

В северо-западном направлении амплитуда аномалий уменьшается и они сливаются в единую широкую полосу. Для оценки распределения источников аномалий по глубинам авторами была выполнена процедура разделения наблюденного поля по глубинам до источников, что позволило создать 


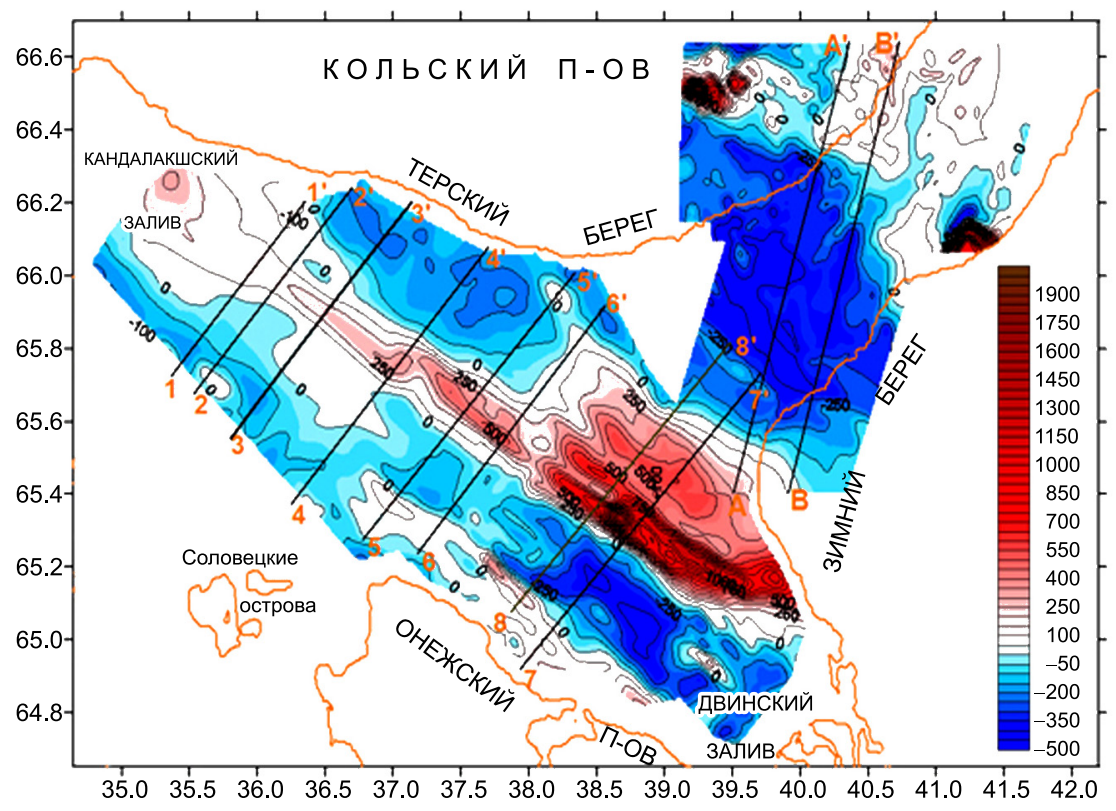

(a)

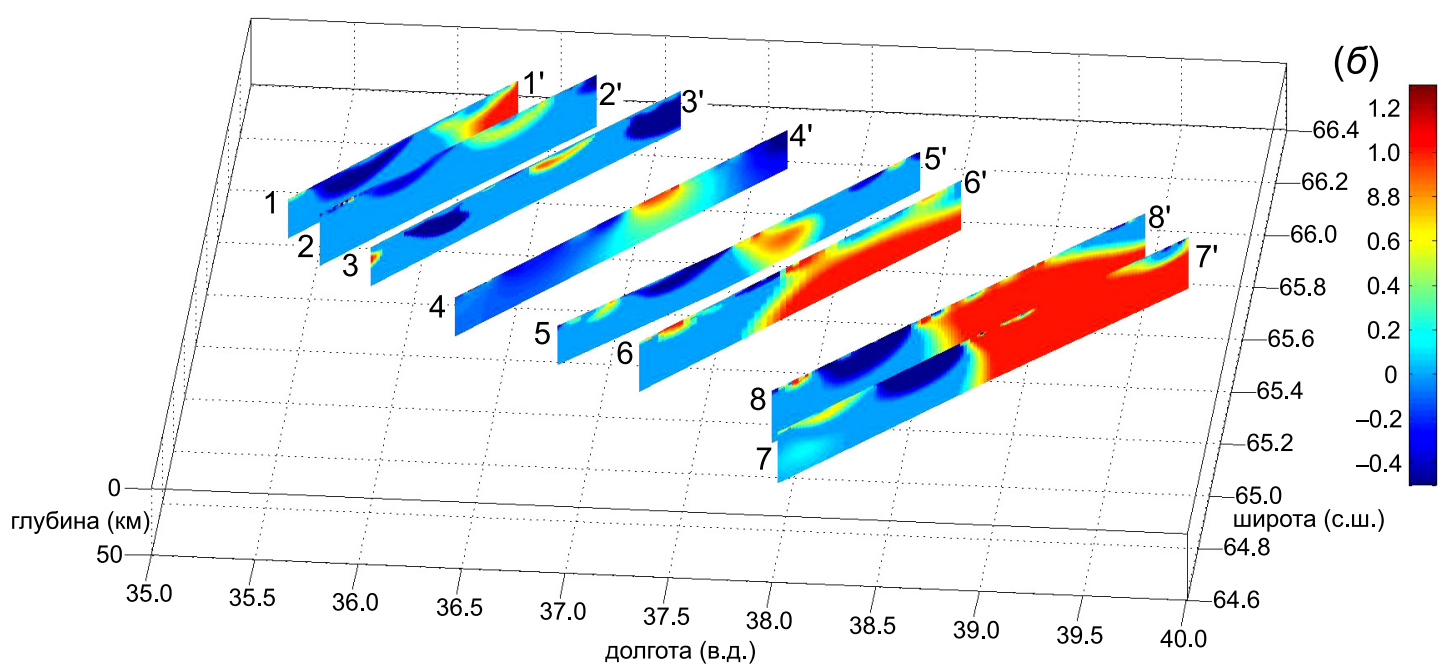

Рис. 3. Карта аномального магнитного поля бассейна Белого моря $(a)$ и эшелон моделей распределения эффективной намагниченности в формате 2D по профилям 1-1' ... 8-8' (внизу шкала в A/м), показанным на рис. 3, $a$ (б).

Fig. 3. Map of the anomalous magnetic field of the White Sea basin $(a)$ and series of models showing the effective magnetization distribution patterns in the 2D format along profiles 1-1' ... 8-8' (bottom: scale in A/m), which are shown in Fig. 3, $a$ (б).

модель магнитоактивного слоя изучаемой площади. Эта модель представлена тремя структурными уровнями (горизонтами), каждый из которых отражает определенный этап формирования изучаемой площади (рис. 4).

Нижний структурный уровень (основание магнитоактивного слоя) представлен крупными блоками, преимущественно северо-западного простирания. Наибольшие глубины нижних и верхних кромок определяются в центральной части модели, где они расположены в диапазонах 15-13 км и 9-7 км соответственно. Эта область наибольших глубин вытянута с северо-запада на юго-восток и представлена двумя крупными блоками. Северный блок имеет протяженность 110 км, а его поперечный размер составляет 40 км, размеры южного блока составляют соответственно 105 и 30 км. Между собой они разделены узкой зоной северовосточного простирания, которая совпадает с выделяемым в этом месте разломом того же простирания. Вдоль границ выделяемой области наблюдается значительное уменьшение глубин нижних кромок до 10-8 км, а верхних до 6-4 км. Оценки глубин верхних и нижних кромок источников магнитных аномалий оказались близки к результатам сейсмических работ ОАО МАГЭ, которые показали, 


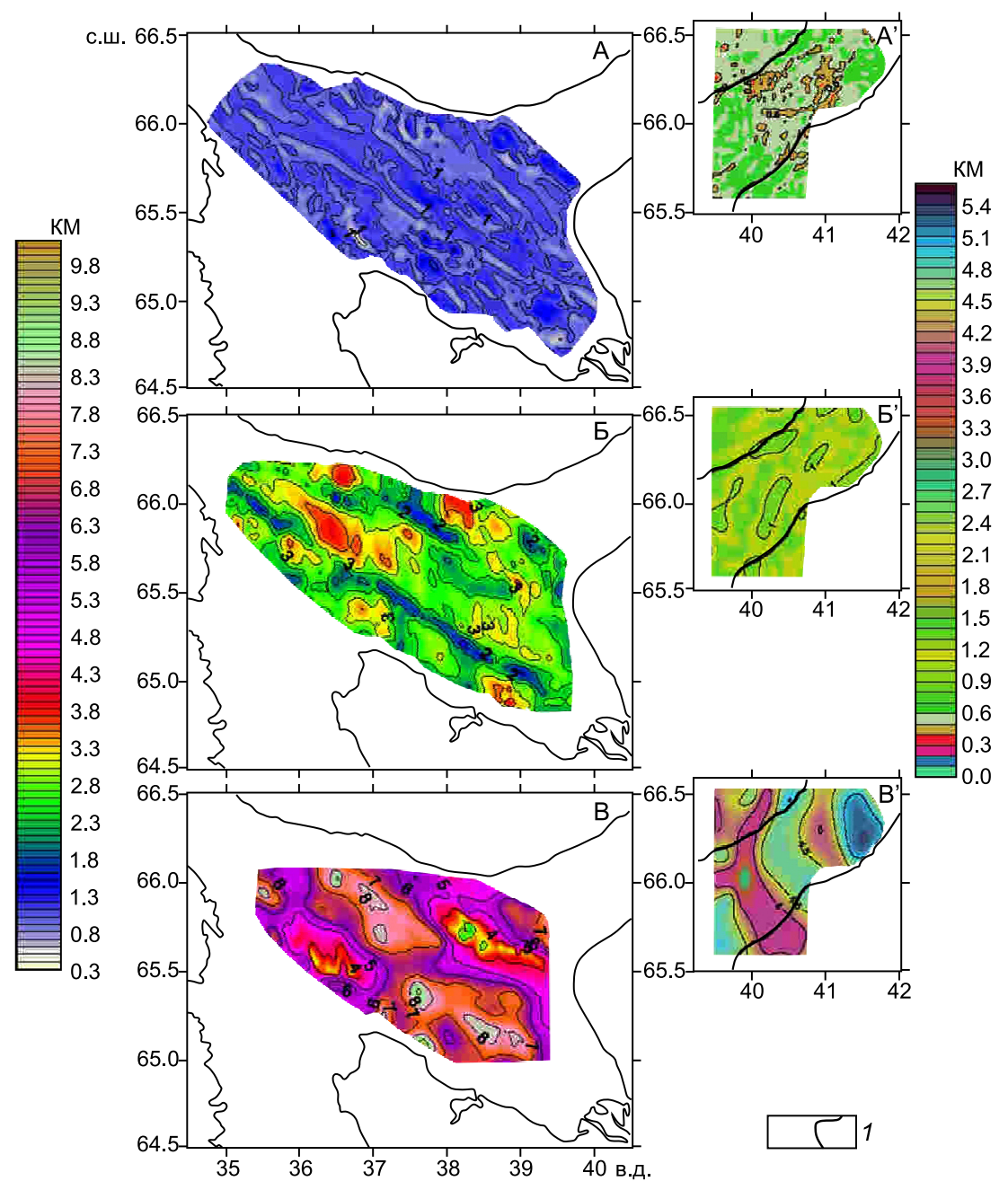

Рис. 4. Положение верхних кромок источников магнитных аномалий в акватории Белого моря.

A - положение верхнего структурного уровня в Центральном бассейне. А' - положение верхнего структурного уровня в проливе Горло. Б - положение среднего структурного уровня в Центральном бассейне. Б' - положение верхнего структурного уровня в проливе Горло. В - положение нижнего структурного уровня в Центральном бассейне. В' - положение нижнего структурного уровня в проливе Горло. 1 - береговая линия.

Fig. 4. Positions of the upper edges of the magnetic anomaly sources in the White Sea.

Positions of the layers: A - top structural layer in the Central basin. A' - top structural layer in the Gorlo Strait. $\mathrm{B}$ - middle structural layer in the Central basin. ' $^{\prime}$ - top structural layer in the Gorlo Strait. B - bottom structural layer in the Central basin. B' - bottom structural layer in the Gorlo Strait. 1 - coastal line.

что глубина погружения кристаллического фундамента Кандалакшского грабена составляет 8-9 км [Zhuravlev, 2007].

Сопоставление границ нижнего структурного уровня с «Тектонической картой Белого моря» [Baluev, 2012] показало, что наиболее глубокая область нижнего горизонта совпадает в плане с Онежско-Кандалакшским рифтом, а ее северная и южная границы, вдоль которых наблюдается уменьшение глубин, совпадают с основными разломными ограничениями, проходящими по границе рифтогенных грабенов с выступами кристаллического фундамента (Карельский и Архангельский выступы). Наиболее глубокая часть нижнего струк- турного горизонта (область Онежско-Кандалакшского рифта) отмечается также на тектонической карте Белого моря как область современного грабенообразования, в пределах которой выделяются эпицентры землетрясений интенсивностью более 3 баллов, что свидетельствует о современной тектонической активности в этом регионе. По мнению авторов, выделяемый нижний структурный уровень отражает рифтовый этап эволюции Беломорского подвижного пояса в среднем и позднем рифее, характеризующийся проявлением континентального рифтогенеза. Безусловно, здесь следует учитывать и строение самого кристаллического фундамента в пределах грабена, в состав которого 


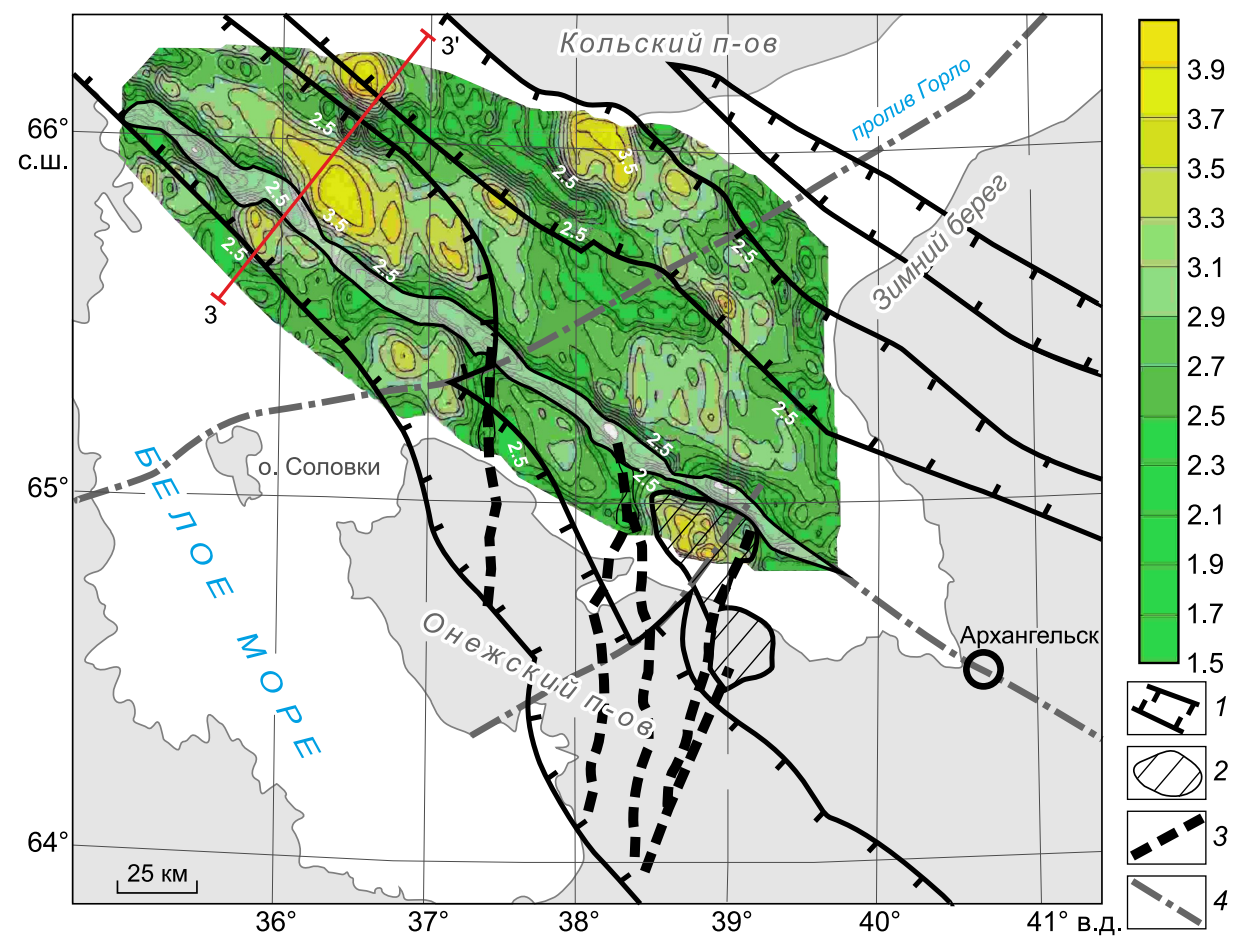

Рис. 5. Схема интерпретации верхней кромки среднего уровня источников магнитных аномалий Центрального бассейна Белого моря (составлена с использованием данных [Baluev et al., 2012; Bush, Kalmykov, 2015]. 1 - рифтогенные грабены; 2 - Ненокское поле развития мелилититовых трубок взрыва; 3 - долеритовые дайки; 4 - разломы.

Fig. 5. Interpretation of the upper edge of the medium level of the magnetic anomaly sources in the White Sea Central basin (compiled using the data from [Baluev et al., 2012; Bush, Kalmykov, 2015]). 1 - riftogenic grabens; 2 - Nenoksa field of mellilitic diatremes; 3 - dolerite dykes; 4 - faults.

входит комплекс глубинных пород, включающий в себя анортозиты, гранулиты и эклогиты, обнажающиеся на северо-восточном плече грабена. Как было отмечено ранее [Baluev et al., 2012], намечается тенденция пространственной приуроченности заложения и активизации рифтообразующих разломов вдоль линейной зоны эксгумации глубинных пород на поверхность, образующую линейную аномалию магнитного поля.

Средний структурный горизонт расположен на уровне осадочного выполнения рифтогенных грабенов и лежит в диапазоне глубин от 6-3 до 4.01.5 км. Этот структурный уровень также представлен узкими, линейно вытянутыми морфоструктурами рельефа поверхности верхней кромки среднего горизонта (телами) преимущественно северозападного простирания, приуроченными к границе Онежско-Кандалакшского рифта с выступами кристаллического фундамента. Наряду с этими телами в пределах среднего структурного уровня выделяется и серия локальных тел северо-северо-западного простирания, связанных, вероятнее всего, с реактивацией палеорифтовой системы Белого моря в среднем палеозое. Следует отметить, что верхняя кромка среднего структурного уровня источ- ников магнитных аномалий Центрального бассейна Белого моря наиболее структурирована, что является отражением, по всей видимости, характера размещения магнитовозмущающих магматических тел основного состава (базитов). Наряду с линейно вытянутыми телами северо-западного простирания здесь выделяется серия тел субмеридионального простирания, которые являются фактическим продолжением в акватории Белого моря даек базитов предположительно вендского возраста, выделенных В.А. Бушем и Б.А. Калмыковым [Bush, Kalmykov, 2015] в пределах Онежского полуострова также по данным аномального магнитного поля. Кроме того, на этом же уровне в пределах акватории Двинского залива выделяется северное окончание (замыкание) Ненокского поля развития трубчатых тел оливиновых мелилититов позднедевонского возраста, внутри которого можно прогнозировать как минимум еще три трубки (рис. 5).

Оценки глубины залегания верхних кромок магнитоактивных тел показывают, что в центральной части грабена они расположены на глубинах 3-4 км. Расчеты верхних кромок послужили основанием для первоначального представления о глубине самого прогиба [Zander et al., 1967]. Результа- 

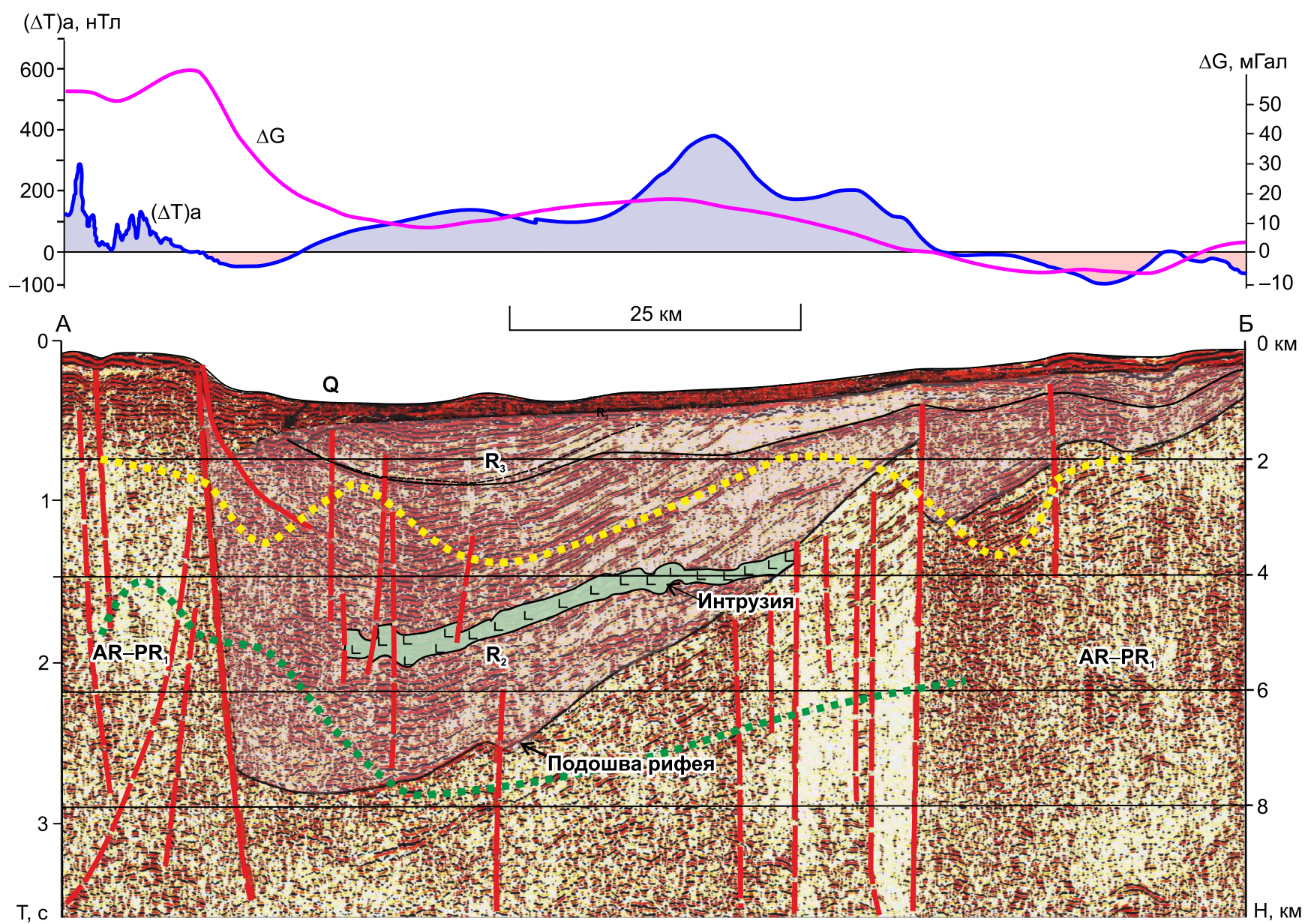

Рис. 6. Геолого-геофизический разрез по профилю МОВ ОГТ 200310 через Кандалакшский грабен [Baluev et al., 2012]. Местоположение профиля соответствует профилю 3-3' на рис. 3 и 5. Пунктирными линиями на разрезе обозначены положения верхних кромок источников магнитных аномалий среднего и нижнего структурного уровня. В верхней части рисунка графики аномального магнитного поля ( $\Delta \mathrm{T})$ а и поля силы тяжести $\Delta \mathrm{G}$ по профилю.

Fig. 6. Geological-geophysical section along Profile МОВ ОГТ 200310 across the Kandalaksha graben [Baluev et al., 2012]. The profile location corresponds to profile 3-3' in Fig. 3 and 5. Dashed lines - positions of the upper edges of the magnetic anomaly sources in the middle and bottom structural layers. Top: curves of the anomalous magnetic field $(\Delta \mathrm{T}) \mathrm{a}$ and gravity field $(\Delta \mathrm{G})$ along the profile.

ты сейсморазведочных работ показали, что глубина Кандалакшского грабена - 8-9 км - в два раза превышает эти оценки. Следовательно, магнитные тела располагаются внутри рифейской осадочной толщи и могут свидетельствовать о проявлениях магматизма, скорее всего, основного состава (рис. 6) [Zhuravlev, 2007].

Верхний структурный уровень расположен в диапазоне глубин от 3.0 до 0.4 км. Этот структурный уровень представлен преимущественно узкими локальными телами северо-западного простирания, унаследованными от более древних и более глубоких горизонтов. Эти тела залегают преимущественно на глубинах от 1 до 3 км. В пределах верхнего структурного горизонта также выделяются тела изометричной формы трубочного типа и тела, имеющие иное простирание, отличное от се- веро-западного. Диапазон глубин залегания для этих тел меняется от 1.0 до 0.2 км. Этот структурный уровень отражает высокочастотную составляющую аномального магнитного поля и связан с сильномагнитными источниками аномалий, расположенными в верхней части выделяемого структурного уровня. Приведенные характеристики позволяют предполагать, что верхний структурный горизонт мог быть сформирован во время последнего этапа тектонической активизации этого региона. Неотектоническая активизация территории Беломорья проявляется системой разрывных дислокаций, которые отчетливо выражены в рельефе дна бассейна Белого моря и в очертаниях береговых линий. Данные сейсмического профилирования Кандалакшского залива свидетельствуют о формировании современного Кандалакшского гра- 
бена, занимающего большую часть одноименного залива и имеющего протяженность около 300 км. Он представляет собой полуграбен с более крутым юго-западным бортом и, судя по рельефу подошвы четвертичных отложений, амплитудой сброса более 200 м [Baluev et al., 2012]. В дальнейшем, во время последнего ледникового периода (в позднем плейстоцене - голоцене), верхняя часть осадочного комплекса была перекрыта флювио-гляциальными отложениями (моренами), которые, видимо, и являются основным источником интенсивных высокочастотных аномалий.

Помимо процедуры разделения АМП и анализа отдельных структурных горизонтов для серии профилей было осуществлено моделирование в формате 2D. Для каждого профиля была выполнена процедура частотного разделения АМП, после чего обратная задача решалась отдельно как для высокочастотной составляющей, обусловленной источниками, расположенными в верхней части коры, так и для низкочастотной составляющей поля, связанной с более глубокими горизонтами земной коры. На рис. 7 приведены модели распределения источников АМП для высокочастотной составляющей. На рис. 7, a, хорошо видно распределение приповерхностных источников с глубиной залегания нижних кромок до 200-300 м, а на рис. 7, б, представлена модель распределения приповерхностных источников с глубиной залегания нижних кромок до 1.5 км. Оба этих примера согласуются с точкой зрения авторов о том, что верхний структурный горизонт был сформирован во время наиболее позднего этапа тектонической активизации, когда проявлялась современная тектоническая активность. Последняя выражалась в диффе- ренцированных движениях земной коры, приведших к современному грабенообразованию, сопровождавшемуся интенсивной денудацией смежных выступов и заполнением молодых впадин продуктами размыва пород основного-ультраосновного состава, в том числе и переотложенных водноледниковых отложений, что создало пеструю картину распределения источников АМП для высокочастотной составляющей. Продвижение ледника с северо-запада на юго-восток, в свою очередь, создало на дне молодого грабена эрозионную ложбину. Эта впадина, глубина которой достигала более 200 м (см. рис. 6), вероятнее всего, выполнена продуктами таяния ледников, моренными и декливиальными образованиями, сползшими в результате тектонических событий с крутых берегов Кандалакшского грабена, где в составе слагающих их пород существенную долю составляют магматические образования основного-ультраосновного состава [Baluev et al., 2012].

Наибольший интерес представляет глубинное строение региона. Модели магнитоактивного слоя для низкочастотной составляющей АМП отображены на рис. 3, б, (эшелон моделей в формате 2D). В юго-восточной части исследуемой площади выделяется массивный, сильномагнитный источник аномалий с эффективной намагниченностью 1.0 1.5 А/м. Видимая протяженность этого объекта вдоль профиля составляет 50-70 км, нижние кромки определяются на глубине порядка 30 км, а верхние кромки на глубинах 4-8 км. К северо-западу происходит уменьшение уровня залегания нижних кромок выделяемого объекта, границы которого поднимаются до глубин 15-25 км, а видимая протяженность вдоль профиля составляет уже 30-40 км.
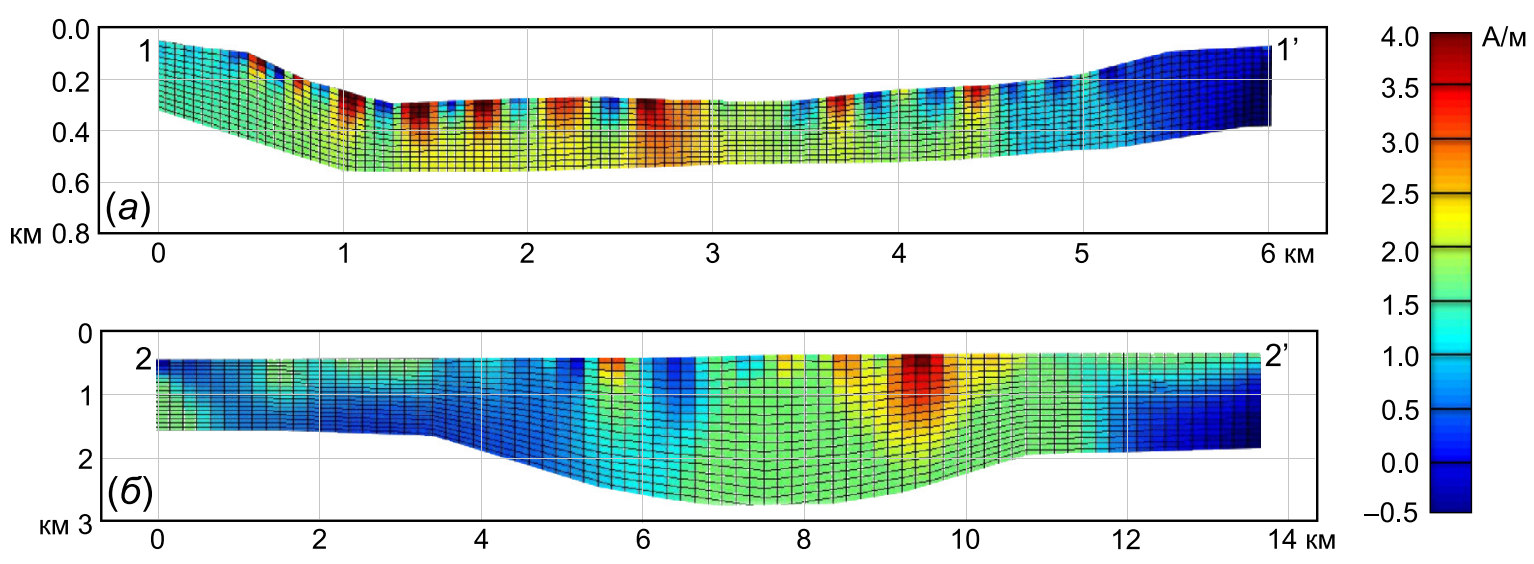

Рис. 7. Пример моделей в формате 2D для локальных аномалий: $(a)$ - распределение приповерхностных источников с глубиной залегания нижних кромок 200-300 м; (б) - распределение приповерхностных источников с глубиной залегания нижних кромок до 1.5 км.

Fig. 7. Examples of the 2D models of local anomalies. Distribution pattern of surface sources: $(a)$ - lower edges at the depths of 200-300 m; (б) - lower edges at the depths to $1.5 \mathrm{~km}$. 
Полученные оценки свидетельствуют, что по мере погружения кристаллического фундамента к юговостоку происходит и погружение источников аномалий. Возможно, заложение Онежско-Кандалакшского рифта сопровождалось проявлением активного магматизма, основной источник которого расположен в юго-восточной части изучаемой площади.

Здесь следует отметить, что в эволюции палеорифтовой системы Белого моря, и в частности Онежско-Кандалакшского палеорифта, установлено как минимум два этапа проявления магматизма: рифейско-вендский основной вулканизм, инициированный непосредственно процессами континентального рифтинга, и среднепалеозойский (позднедевонский) щелочно-ультраосновной магматизм, связанный со среднепалеозойской реактивацией рифтовой системы. Рифейские вулканогеннообломочные породы, вмещающие силлы и дайки диабазов и долеритов, были вскрыты бурением на Онежском п-ове в Онежском грабене палеорифта. Кроме того, характерные аномалии волнового и потенциальных полей предполагают наличие внутри рифейской толщи Кандалакшского грабена таких же магматогенных образований (см. рис. 6). Магматические породы, по-видимому, довольно широко распространены в северо-западной и центральной части Кандалакшского и на юго-востоке Керецкого грабена. Подводящим каналом мог служить мощный разлом - Беломорский шов, который, видимо, и отражается в магнитном поле вышеописанной интенсивной линейной положительной аномалией. При погружении краевых структур Архангельского горста в Керецкий грабен увеличивается и глубина залегания кромок магнитоактивных тел. Характерно, что все тела ориентированы в направлении северо-запад - юго-восток. Это говорит о том, что магматизм активно развивался на этапе заложения рифтогенных прогибов либо был многостадийным и проявлялся впоследствии только вблизи магмоподводящего центра - Беломорской шовной зоны. При этом, как было упомянуто выше, весьма вероятен вклад в структуру аномального магнитного поля Беломорского бассейна древних магматических пород фундамента с высокой намагниченностью.

На сейсмических разрезах МОВ ОГТ Кандалакшского грабена видно (см. рис. 6), что магматогенные породы (интрузия) залегают согласно со слоистостью осадочной толщи в наиболее погруженной части и занимают секущее положение на северовосточном борту Кандалакшского грабена - вблизи предполагаемой магмоподводящей Беломорской зоны разломов. Мощность магматогенных образований увеличивается к депоцентру прогиба и может составлять первые сотни метров. Магмоподводя- щий канал отчетливо проявляется осями дифракции и «столбообразной размытостью» на сейсмической записи с потерей корреляции горизонтов в осадочной толще (см. рис. 6). Подобные эффекты в зоне динамического влияния Беломорского шва могут быть объяснены внедрением магм основного состава с большим количеством ее дериватов флюидов и газов, глубоко проникающих во вмещающие осадочные образования [Zhuravlev, 2007].

Моделирование геолого-геофизического разреза в Белом море на профиле МОГТ-ГСЗ 3-АР подтверждает существование магматического очага под Кандалакшским и Керецким рифтами (рис. 8). Очаг выделяется контрастной магнитной аномалией в Беломорской шовной зоне, прослеживается в нижней коре и, вероятно, связан с мантией [Zhuravlev, 2007]. Как видно на рис. 8, магмоподводящий канал в верхней части разреза расширяется, что, вероятно, обусловлено декомпрессией магмы. Здесь его апофизы имеют юго-западное падение. Но на глубине магмоподводящий канал погружается на северо-восток, в соответствии с общим падением комплексов пород Беломорского пояса.

Среднепалеозойская активизация палеорифтовых структур проявилась во внутриплитном магматизме, представленном роями щелочных даек и трубок взрыва, в том числе и кимберлитового состава, а также сложными кольцевыми массивами щелочно-ультраосновной и щелочной формаций, располагающимися в зонах динамического влияния рифтов Беломорской системы. Ареал проявлений внутриплитного щелочно-ультраосновного магматизма в среднем палеозое представляет собой некий овал, вытянутый примерно на 900 км вдоль простирания рифтовых структур, в пределах которого по составу и характеру проявления магматизма намечается некоторая концентрическая зональность (рис. 9) [Baluev et al., 2012].

Юго-восточная часть ареала, включающая Архангельскую алмазоносную провинцию, наиболее широкая, с наибольшей концентрацией проявлений среднепалеозойского магматизма в основном в виде даек щелочных базальтов и трубок взрыва, в том числе и кимберлитовых. Установлено, что в процессы магмогенерации была вовлечена значительная часть субконтинентальной литосферной мантии, достигавшая глубины 120 км, т.е. простиравшаяся на всю глубину мантийной фации гранатовых лерцолитов, что предполагает плюм-литосферное взаимодействие. Видимо, крупная положительная магнитная аномалия, фиксируемая в пределах акватории Двинского залива Белого моря, маркирует насыщенность земной коры глубинными комагматами основного и ультраосновного состава, возможно, даже двух этапов проявления магматизма в Беломорском регионе. 


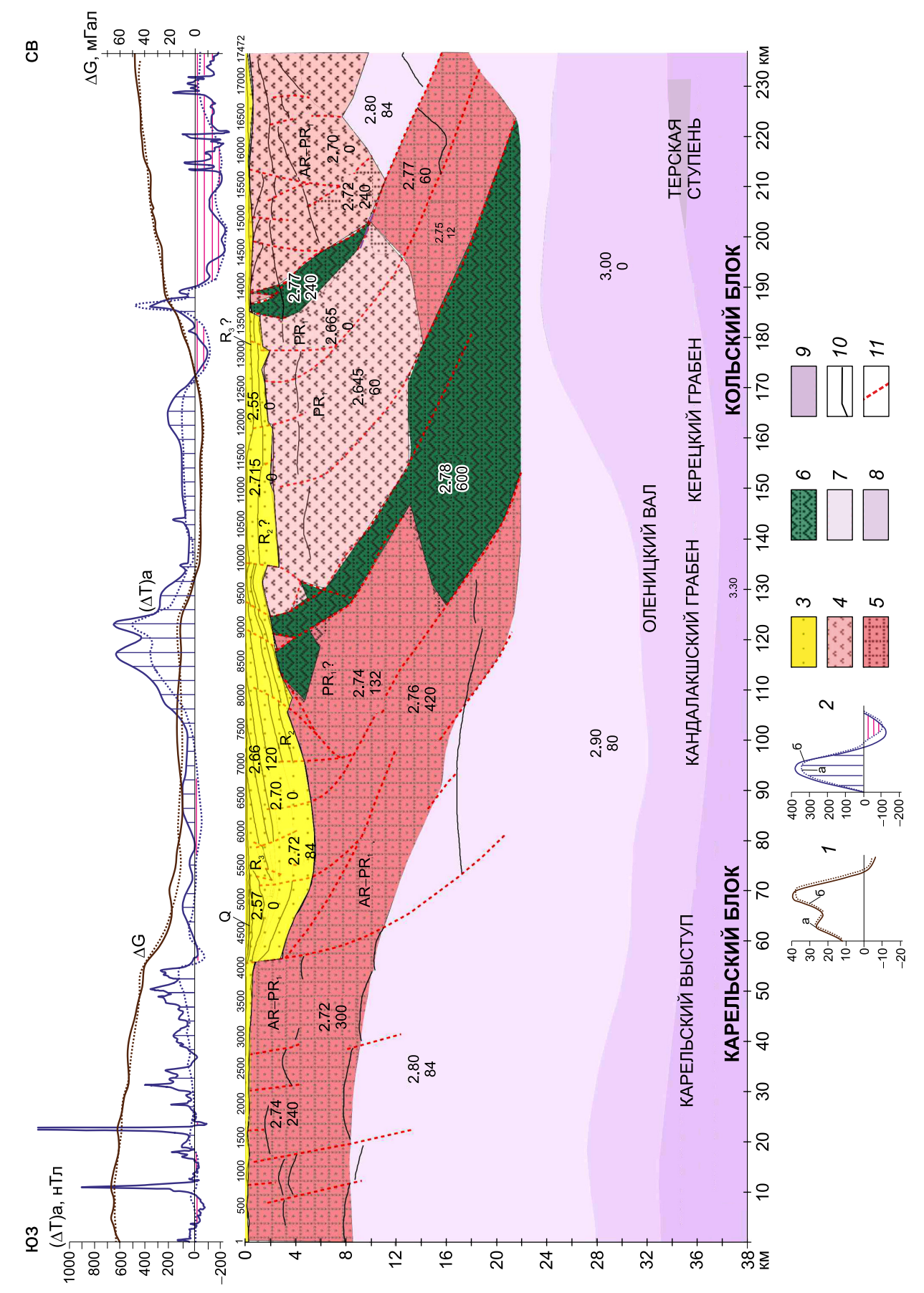




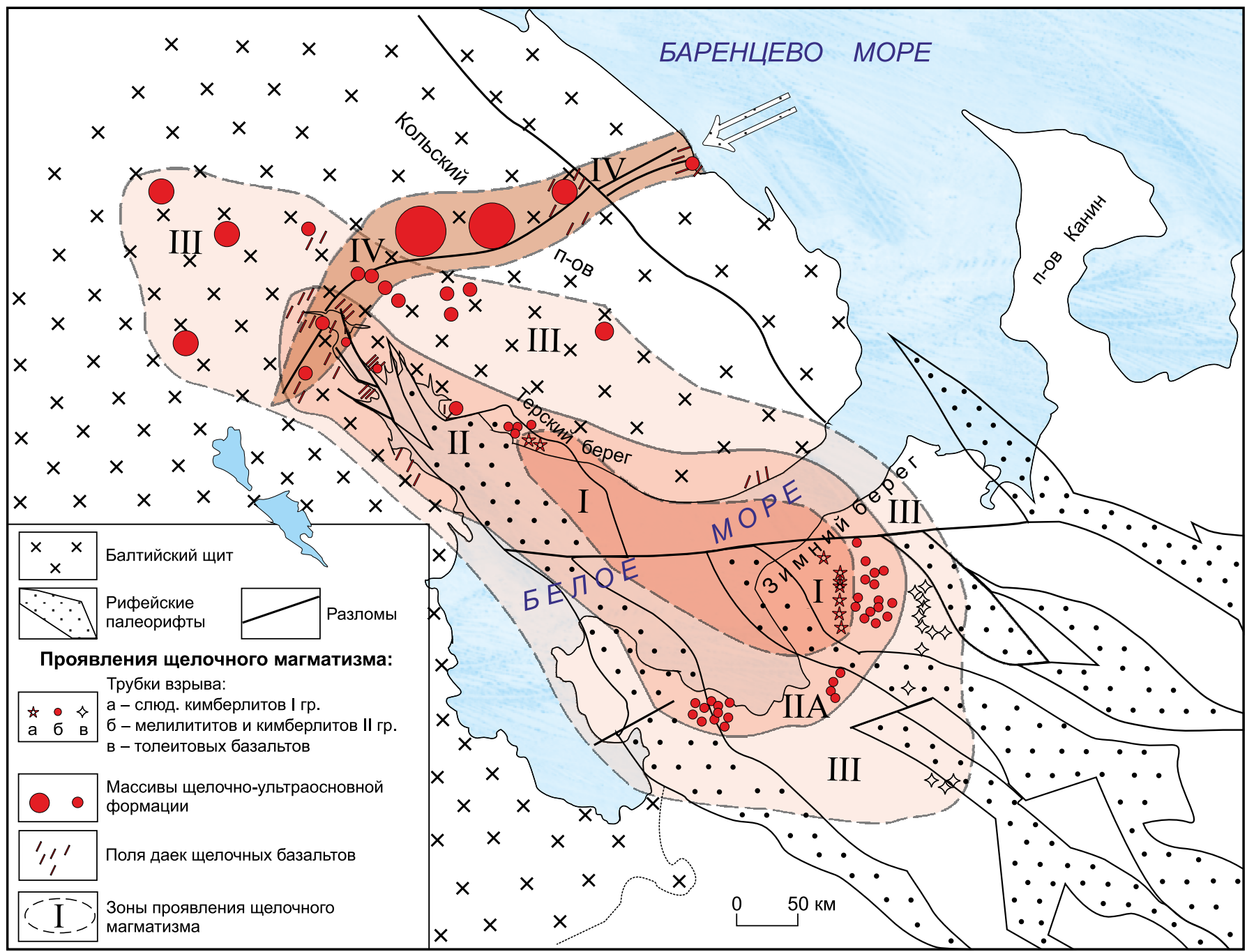

Рис. 9. Схема зональности проявлений внутриплитного щелочного магматизма в среднем палеозое в пределах зоны динамического влияния рифтовой системы Белого моря: I - слюдяных кимберлитов, II - мелилититовая (а - диатремового, б - дайкового), III - периферийная, IV - Хибино-Контозерская тектоническая зона.

Fig. 9. Schematic map showing areas with intraplate alkaline magmatism in the Middle Paleozoic within the zone of dynamic influence of the White Sea rift system: I - mica kimberlites, II - mellitite (a - diatreme, б - dyke), III - peripheral, IV Khibiny-Kontozero tectonic zone.

Обращает на себя внимание то, что простирания выделенных горизонтов совпадают с простираниями соответствующих горизонтов Мезенской площади [Brusilovsky, Bush, 2015] и расположены они приблизительно в одном глубинном диапазоне. Это позволяет сделать вывод о том, что условия формирования магнитоактивного слоя этих площадей были одинаковыми.

\section{5. АНАЛИЗ МАТЕРИАЛОВ МАГНИТНЫХ ИССЛЕДОВАНИЙ ПРОЛИВА ГОРЛО}

Анализ АМП пролива Горло позволил авторам создать модель магнитоактивного слоя, которая так же, как и модель магнитоактивного слоя для
Кандалакшского и Двинского заливов, представлена тремя структурными уровнями. Для каждого выделенного горизонта (уровня) были рассчитаны геометрические параметры и величина эффективной намагниченности (см. рис. 4).

Нижний структурный уровень (горизонт), формирующий основание магнитоактивного слоя, представлен положительной, линейно вытянутой структурой северо-западного простирания, разделяющей две отрицательных структуры того же простирания. Сравнение границ нижнего структурного уровня с тектонической картой Белого моря (см. рис. 2) показало, что его границы совпадают с основными разломными ограничениями, проходящими по границе палеорифтов (Лешуконского с севера и Керецкого с юга) с выступом кристалличе- 
ского фундамента (Товский выступ). Этот структурный уровень фактически отражает рельеф кровли фундамента, другими словами, рифтовый этап эволюции Беломорского подвижного пояса в среднем и позднем рифее, характеризующийся мощным проявлением континентального рифтогенеза [Baluev et al., 2012].

Средний структурный горизонт, ограниченный верхней кромкой на уровне 1.4-1.0 км и нижней кромкой 2.0-3.2 км, расположен в верхней части консолидированного фундамента и представлен узкими, линейно вытянутыми телами, преимущественно северо-восточного простирания, ортогональными структурам нижнего горизонта, но конформными простиранию пролива Горло Белого моря, представляющего собой современный грабен, который заложился вдоль системы разломов северо-восточного простирания. Смена простирания выделяемых в пределах среднего структурного горизонта тел с северо-западного в нижнем горизонте на северо-восточное в среднем может быть связана с активизацией именно этих поперечных структур, которые играли значительную роль в формировании бассейна Белого моря. Помимо того, что позднекайнозойские сбросы определили границы современного грабена пролива Горло, материалы сейсмоакустического профилирования показали существование системы разрывных нарушений северовосточного простирания в породах, подстилающих четвертичные отложения в центральной части грабена. В рельефе дна каждому из этих разрывов соответствует отрицательная форма в виде ложбины или рва, что свидетельствует о «живом» характере этих дислокаций. С точки зрения унаследованности грабен пролива Горло заложен над ступенчатой структурой фундамента, погружающегося от Балтийского щита под чехол Мезенской синеклизы.

Верхний структурный уровень (горизонт) расположен в верхней части осадочного чехла и представлен преимущественно локальными телами разнообразной формы и разного простирания и отражает высокочастотную составляющую поля. Приведенные характеристики позволяют предполагать, что верхний структурный горизонт отражает те неоднородности на поверхности или в приповерхностном слое вендского осадочного чехла, выполняющего дно пролива Горло, которые возникли в результате неотектонических подвижек фундамента. В дальнейшем, во время последнего оледенения (поздний плейстоцен - голоцен), в самом верхнем горизонте сформировались ледниково-осадочные отложения (морены), которые, вероятно, и являются основным источником высокочастотных аномалий.

Наряду с процедурой разделения АМП и выделением на ее основе трех структурных горизонтов, авторами была решена обратная задача в формате 2.5D [Cooper, 1997]. Моделирование было выполнено для двух профилей А-A' и В-B' (рис. 10). Полученные модели представлены набором источников магнитных аномалий, расположенных на разных структурных уровнях и отражающих различные этапы активизации внутриплитного магматизма палеорифтовой системы Белого моря. При этом глубины, на которых выделяются источники аномалий, лежат в диапазоне, выделяемом при процедуре разделения АМП.

Сопоставление графиков магнитного поля с гравиметрическими данными по тем же профилям позволило установить, что магнитные и гравитационные аномалии находятся в противофазе: к отрицательной длиннопериодной магнитной аномалии приурочена положительная аномалия силы тяжести (см. рис. 8). Такое взаимоотношение аномальных полей, не характерное для рассматриваемой области в целом, является отличительной чертой Терско-Зимнегорского блока Беломорского подвижного пояса, перекрытого в данном случае водами акватории пролива Горло. Он, видимо, сложен более плотными породами нижней части гранитогнейсового основания. Характер аномальных полей и результаты бурения говорят о том, что вещественные комплексы этого блока прослеживаются в юго-восточном направлении через пролив Горло Белого моря на Зимний берег, где слагают выступы фундамента и, возможно, северный борт Керецкого грабена. Следует отметить, что в пределах блока на Терском и Зимнем берегах выявлены трубки мелилититов, а также алмазоносных кимберлитов и лампроитов. Возможно, существованием еще одного поля кимберлитовых трубок в пределах акватории пролива Горло можно объяснить наличие относительно положительной магнитной аномалии на фоне отрицательного магнитного поля в районе 60-го километра профиля А-A'. Мощность земной коры в пределах Терско-Зимнегорского блока увеличивается в восточном направлении от 36 км на Кольском п-ове до 40 км на Зимнем берегу. Результаты работ на профиле 3-АР в проливе Горло Белого моря говорят о том, что верхняя часть коры блока утонена (мощность менее 10 км) и отличается высокой скоростью сейсмических волн (6.34 км/с).

Следует отметить и тот факт, что в северо-восточной части обоих профилей положительная длиннопериодная магнитная аномалия соответствует Восточно-Кольскому блоку (домену) Центрально-Кольского геоблока, а градиент совпадает с границей последнего с Беломорским подвижным поясом, вдоль которой протягивается раннепротерозойский Имандра-Варзуга-Устьпонойский зеленокаменный пояс, представляющий собой межблоковую грабен-синклиналь, выполненную вулкано- 

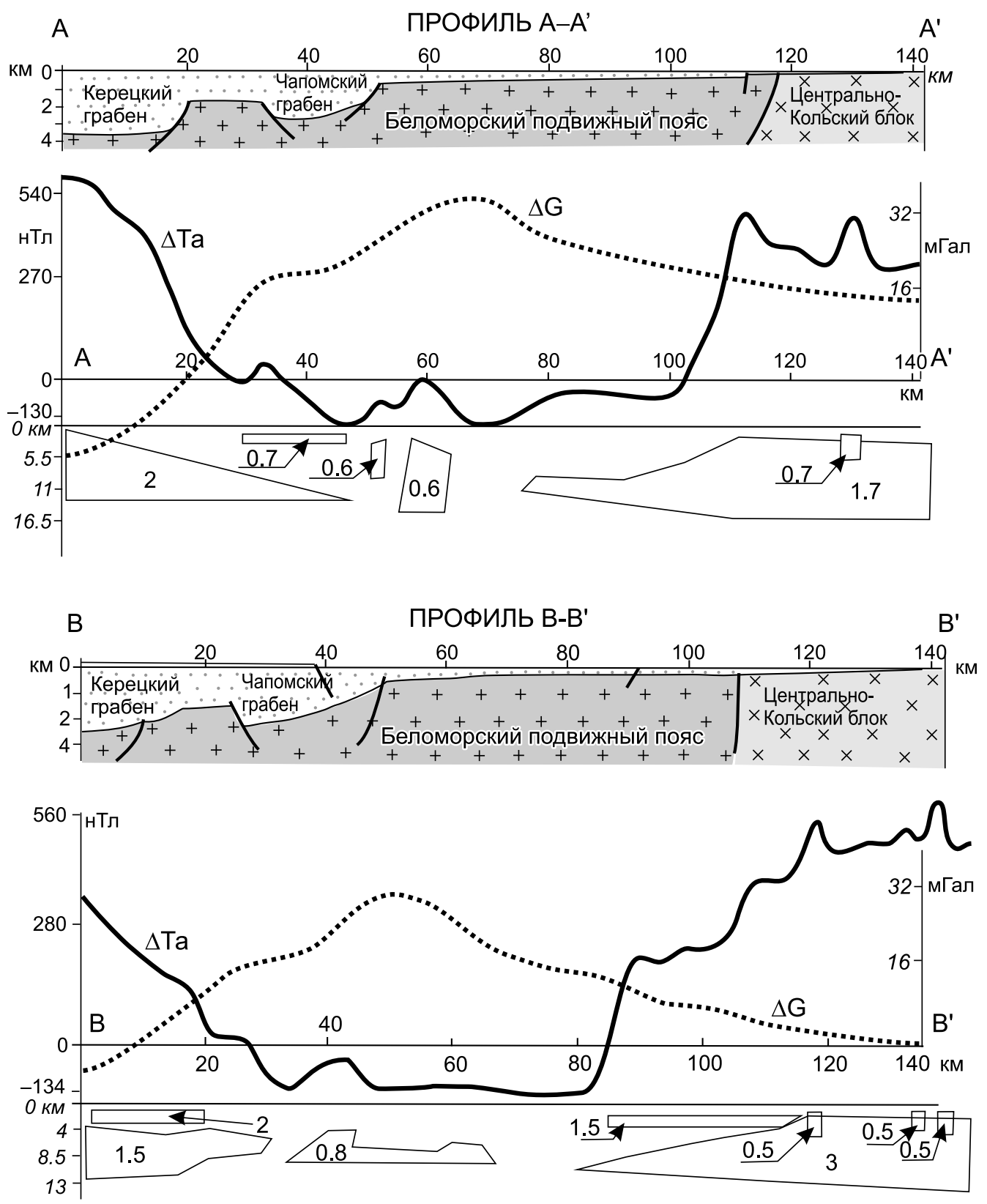

31

1.7

Рис. 10. Модели в формате 2.5D для пролива Горло Белого моря. 1 - намагниченность в A/м.

Fig. 10. 2.5D models of the Gorlo Strait (White Sea). 1 - magnetization $(\mathrm{A} / \mathrm{m})$.

генно-осадочным комплексом пород с содержанием палеопротерозойских коматиитов в разрезе.

\section{6. ЗАКЛЮЧЕНИЕ}

Таким образом, в результате анализа и комплексной интерпретации аномального магнитного поля и других геолого-геофизических данных авторами была создана модель строения и формирования магнитоактивного слоя палеорифтовой си- стемы Белого моря. Исследования показали следующее:

1. Магнитоактивный слой палеорифтовой системы Белого моря имеет сложное строение, которое отражает основные этапы тектонической эволюции Беломорского региона - от среднего и позднего рифея до событий последнего ледникового периода (в позднем плейстоцене - голоцене). Вряд ли можно с достаточной достоверностью выделить более ранние этапы эволюции земной коры бассейна Белого моря среди составляющих 
магнитного поля, так как древний кристаллический фундамент в пределах акватории перекрыт мощной (7-8 км) терригенной толщей, которая, в свою очередь, содержит магматические тела (прослои?) основного состава с высокой намагниченностью.

2. Модель магнитоактивного слоя представлена тремя структурными уровнями (горизонтами), каждый из которых отражает определенный этап формирования изучаемой площади.

Так, нижний структурный уровень (основание магнитоактивного слоя), по мнению авторов, отражает структуру кровли фундамента, сформировавшуюся в рифтовый этап эволюции Беломорского подвижного пояса в среднем и позднем рифее, характеризующийся проявлением континентального рифтогенеза [Baluev et al., 2012].

Средний структурный горизонт отражает среднепалеозойский (позднедевонский) этап реактивации рифтовой системы Белого моря, который характеризуется в основном проявлением щелочноультраосновного магматизма и представлен роями щелочных даек и трубок взрыва, в том числе кимберлитового состава.

Верхний структурный уровень отражает высокочастотную составляющую аномального магнитного поля и связан с сильномагнитными источниками аномалий, расположенными в верхней части выделяемого структурного уровня. Характеристики этого структурного уровня позволяют предполагать, что верхний горизонт мог быть сформирован во время последнего этапа тектонической активизации этого региона.

3. Модели магнитоактивного слоя для низкочастотной составляющей АМП отражают глубинное строение земной коры Беломорского бассейна, в юго-восточной части которого сильномагнитным источником аномалий с глубиной нижних кромок до 30 км является насыщенность коры продуктами проявлений магматизма основного (рифей - венд) и щелочно-ультраосновного (средний палеозой) состава. Об этом свидетельствует и продолжение этих аномалий за пределы морского бассейна на суше в районе Архангельской кимберлитовой провинции, где известные поля кимберлитовых и базальтовых трубок с сопутствующими им силлами и дайками щелочного состава располагаются на высокостоящих блоках фундамента и в бортах авлакогенных впадин. Видимо, здесь происходит наиболее активное плюм-литосферное взаимодействие. Выклинивание и воздымание магнитоактивного слоя к северо-западу вдоль простирания Онежско-Кандалакшского рифта можно связать с Беломорским глубинным разломом, который являлся магмоподводящим каналом от центральной части плюма, что подтверждается наличием магматических тел основного состава в центральной части осадочного клина, выполняющего Кандалакшский рифтогенный грабен, по данным морского сейсмического профилирования МОВ ОГТ.

4. Комплексный анализ АМП в пределах акватории Белого моря позволил спрогнозировать наличие магматических тел различной морфологии в верхней части земной коры: продолжение субмеридиональных даек базитов и замыкание Нёнокского поля трубок мелилититов Онежского п-ва в акватории Двинского залива, а также в проливе Горло вблизи Зимнего берега - еще одного поля кимберлитовых трубок.

\section{7. БЛАГОДАРНОСТИ}

Авторы выражают глубокую благодарность руководству ОАО МАГЭ, в частности начальнику партии В.А. Журавлеву, за предоставленные материалы геофизических съемок, послуживших источником исследований авторов данной статьи. Работа выполнена в соответствии с государственными заданиями № 0149-2018-0005 и 0135-2016-0012 при частичной финансовой поддержке Программы президиума РАН № 19 (проект № 0135-2018-0040) и при поддержке РФФИ (проекты №18-05-00316 и 18-05-00485).

\section{8. ЛИТЕРАTУРA / REFERENCES}

Aplonov S.V., Fedorov D.L. (Eds.), 2006. Geodynamics and Possible Oil and Gas Potential of the Mezensk Sedimentary Basin. Nauka, Saint Petersburg, 319 p. (in Russian] [Геодинамика и возможная нефтегазоносность Мезенского осадочного бассейна / Ред. С.В. Аплонов, Д.Л. Федоров. СПб.: Наука, 2006. 319 с.].

Baluev A.S. (Ed.), 2012. Tectonic Map of the White Sea and Adjacent Territories. Scale 1:500000. IPP Kuna, Moscow (in Russian) [Тектоническая карта Белого моря и прилегающих территорий. Масштаб 1:500000 / Ред. А.С. Балуев. М.: ИПП «Куна», 2012].

Baluev A.S., Przhiyalgovskii E.S., Terekhov E.N., 2009a. New data on tectonics of Onega-Kandalaksha paleorift (the White Sea). Doklady Earth Sciences 425 (2), 249-252. https://doi.org/10.1134/S1028334X09020160.

Baluev A.S., Zhuravlev V.A., Przhiyalgovskii E.S., 2009b. New data on structure of the central part of the White Sea paleorift system. Doklady Earth Sciences 427A (6), 891-896. https://doi.org/10.1134/S1028334X09060014. 
Baluev A.S., Zhuravlev V.A., Terekhov E.N., Prahiyalgovsky E.S., 2012. Tectonics of the White Sea and Adjacent Areas. The Explanatory Notes to "The Tectonic Map of the White Sea and Adjacent Areas", at a Scale of 1:1500000. GEOS, Moscow, 104 p. (in Russian) [Балуев А.С., Журавлёв В.А., Терехов Е.Н., Пржиялговский Е.С. Тектоника Белого моря и прилегающих территорий. (Объяснительная записка к «Тектонической карте Белого моря и прилегающих территорий» масштаба 1:500000). М.: ГЕОС, 2012. 104 с.]

Brusilovskii Yu.V., Ivanenko A.N., Popov K.V., Filin A.M., 2003. Geomagnetic survey in the White Sea. Oceanology 43 (2), 258-262.

Brusilovsky Yu.V., Bush V.A., 2015. A model of the magnetically active layer of Western Mezen syneclise. Geophysical Research 16 (1), 69-76 (in Russian) [Брусиловский Ю.В., Буш В.А. Модель магнитоактивного слоя восточной части Мезенской синеклизы // Геофизические исследования. 2015. Т. 16. № 1. С. 69-76].

Bush V.A., Kalmykov B.A., 2015. New data on Pre-mezozoic intraplate magmatism in the East European platform. Geotectonics 49 (5), 395-410. https://doi.org/10.1134/S0016852115050027.

Cooper G.R.J., 1997. Forward modelling of magnetic data. Computers \& Geosciences 23 (10), 1125-1129. https:// doi.org/10.1016/S0098-3004(97)00099-X.

Dobrynina M.I., 1992. Riftogenesis in the Precambrian geological history of the northern regions of the USSR. In: F.P. Mitrofanov, V.I. Bolotov (Eds.), Deep structure and geodynamics of crystalline shields of the European part of the USSR. Publishing House of KSC RAS, Apatity, p. 71-78 (in Russian) [Добрынина М.И. Рифтогенез в геологической истории докембрия северной части Русской плиты // Глубинное строение и геодинамика кристаллических щитов европейской части СССР / Ред. Ф.П. Митрофанов, В.И. Болотов. Апатиты: Изд-во КНЦ $\mathrm{PAH}, 1992$. C. 71-78].

Gafarov R.A., 1963. The Structure of the Precambrian Basement of the Northern Region of the Russian Plate. Publishing House of the USSR Acad. Sci., Moscow, 212 p. (in Russian) [Гафаров Р.А. Строение докембрийского фундамента Севера Русской плиты. М.: Изд-во АН СССР, 1963. 212 с.].

Ivanenko A.N., Brusilovskiy Yu.V., Filin A.M., Shishkina N.A., 2012. Methods of processing and interpretation of marine magnetic data in the works on oil and gas fields in shallow water. Geofizika (The Russian Geophysics Journal) (3), 60-70 (in Russian) [Иваненко А.Н., Брусиловский Ю.В., Филин А.М., Шишкина Н.А. Методики обработки и интерпретации морских магнитных данных при работах на месторождениях нефти и газа на мелководье // Геофизика. 2012. № 3. С. 60-70].

Kazanin G.S., Zhuravlev V.A., Pavlov S.P., 2006. Structure of the sedimentary cover and petroleum capacities of the White Sea. Burenie i Neft (Drilling and Oil) (2), 26-28 (in Russian) [Казанин Г.С., Журавлев В.А., Павлов С.П. Структура осадочного чехла и перспективы нефтегазоносности Белого моря // Бурение и нефть. 2006. № 2. C. 26-28].

Kharitonov L.Ya., 1955. The main features of the stratigraphy and tectonics of the eastern regions of the Baltic Shield. In: Proceedings of the $3^{\text {rd }}$ session of the Commission for determining the absolute ages of geological formations. Publishing House of the USSR Acad. Sci., Moscow, p. 51-77 (in Russian) [Харитонов Л.Я. Основные черты стратиграфии и тектоники восточной части Балтийского щита // Труды III сессии комиссии по определению абсолютного возраста геологических формаций. М.: Изд-во АН СССР, 1955. С. 51-77].

Konstantinovsky A.A., 1977. Riphean Onega-Kandalaksha graben of the East European platform. Geotektonika (Geotectonics) (3), 38-45 (in Russian) [Константиновский A.A. Рифейский Онежско-Кандалакшский грабен Восточно-Европейской платформы // Геотектоника. 1977. № 3. С. 38-45].

Last B.J., Kubik K., 1983. Compact gravity inversion. Geophysics 48 (6), 713-721. https://doi.org/10.1190/1.1441501.

Portniaguine O., Zhdanov M.S., 1999. Focusing geophysical inversion images. Geophysics 64 (3), 874-887. https:// doi.org/10.1190/1.1444596.

Valeev R.N., 1978. Aulacogenes of the East European Platform. Nedra, Msocow, 152 p. (in Russian) [Валеев Р.Н. Авлакогены Восточно-Европейской платформы. М.: Недра, 1978. 152 с.].

Zander V.N., 1972. Geological Structure and Ore-Bearing Capacities of the Basement of the Baltic Shield Slopes. Nedra, Leningrad, 152 p. (in Russian) [Зандер В.Н. Геологическое строение и перспективы рудоносности фундамента склонов Балтийского щита. Л.: Недра, 1972. 152 с.].

Zander V.N., Tomashunas Yu.I., Berkovsky A.N., Suvorova L.V., Dedeev V.A., Kratts K.O., 1967. Geological Structure of the Basement of the Russian Plate. Nedra, Leningrad, 124 p. (in Russian) [Зандер В.Н., Томашунас Ю.И., Берковский А.Н., Суворова Л.В., Дедеев В.А., Крати К.О. Геологическое строение фундамента Русской плиты. Л.: Недра, 1967. 124 c.].

Zhuravlev V.A., 2007. The crustal structure of the White Sea region. Razvedka i Okhrana Nedr (Exploration and Protection of Mineral Resources) (9), 22-26 (in Russian) [Журавлёв В.А. Структура земной коры Беломорского региона // Разведка и охрана недр. 2007. № 9. С. 22-26].

Zhuravlev V.A., Pavlov S.P., Shipilov E.V., 2007. The structure of the basement and the sedimentary cover of the White Sea sector of the East European Platform. In: G.G. Matishov (Ed.), Complex studies of the processes, Characteristics and resources of the Russian seas of the North European basin (Project of the Studies of Nature of the World Ocean Sub-Programme in the World Ocean Federal Programme). Vol. 2. Publishing House of KSC RAS, Apatity, p. 302-310 (in Russian) [Журавлёв В.А., Павлов С.П., Шипилов Э.В. Структура фундамента и осадочного чехла 
A.S. Baluev et al.: The crustal structure of Onega-Kandalaksha paleorift...

Беломорского сектора Восточно-Европейской платформы // Комплексные исследования процессов, характеристик и ресурсов российских морей Северо-Европейского бассейна (проект подпрограммы «Исследование природы Мирового океана» федеральной целевой программы «Мировой океан») / Ред. Г.Г. Матишов. Вып. 2. Апатиты: Изд-во КНЦ РАН, 2007. С. 302-310].

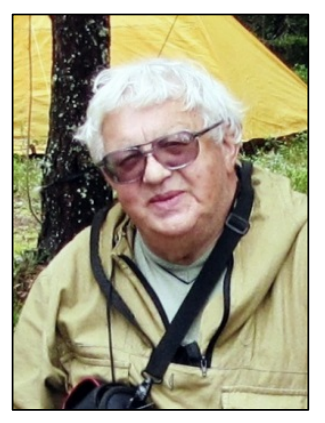

Александр Сергеевич Балуев, докт. геол.-мин. наук, в.н.с.

Геологический институт РАН

119017, Москва, Пыжевский пер., 7, Россия

e-mail: albaluev@yandex.ru

Alexander S. Baluev, Doctor of Geology and Mineralogy, Lead Researcher Geological Institute of RAS

7 Pyzhevsky Lane, Moscow 119017, Russia

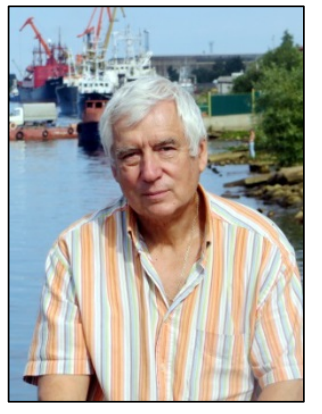

Юрий Викторович Брусиловский, канд. геол.-мин. наук, с.н.с.

Институт океанологии им. П.П. Ширшова РАН

117997, Москва, Нахимовский пр., 36

e-mail: ura77777@rambler.ru

Yuriy V. Brusilovsky, Candidate of Geology and Mineralogy, Senior Researcher

P.P. Shirshov Institute of Oceanology of RAS

36 Nachimovsky ave., Moscow 117997, Russia

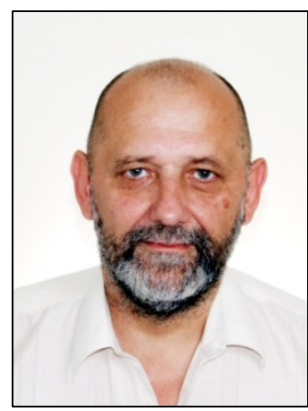

Александр Николаевич Иваненко, канд. геол.-мин. наук, с.н.с.

P.P. Shirshov Institute of Oceanology of RAS

36 Nachimovsky ave., Moscow 117997, Russia

e-mail: ivanenko.ocean@gmail.com

Alexander N. Ivanenko, Candidate of Geology and Mineralogy, Senior Researcher P.P. Shirshov Institute of Oceanology of RAS

36 Nachimovsky ave., Moscow 117997, Russia 